Abandoned in the Heartland 


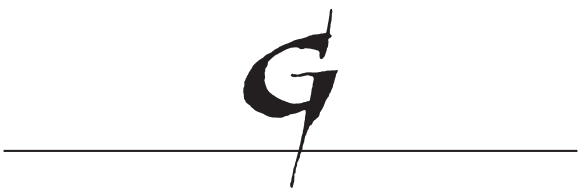

THE GEORGE GUND FOUNDATION IMPRINT IN AFRICAN AMERICAN STUDIES The George Gund Foundation has endowed this imprint to advance understanding of the history, culture, and current issues of African Americans. 


\title{
Abandoned in the Heartland
}

\author{
Work, Family, and Living \\ in East St. Louis
}

Jennifer F. Hamer

\section{甲}

UNIVERSITY OF CALIFORNIA PRESS

Berkeley Los Angeles London 
University of California Press, one of the most distinguished university presses in the United States, enriches lives around the world by advancing scholarship in the humanities, social sciences, and natural sciences. Its activities are supported by the UC Press Foundation and by philanthropic contributions from individuals and institutions. For more information, visit ww w.ucpress.edu.

University of California Press

Berkeley and Los Angeles, California

University of California Press, Ltd.

London, England

(C) 20Ir by The Regents of the University of California

Library of Congress Cataloging-in-Publication Data

Hamer, Jennifer.

Abandoned in the heartland : work, family, and living in East St. Louis / Jennifer F. Hamer.

p. $\mathrm{cm}$.

Includes bibliographical references and index.

ISBN 978-0-520-26931-6 (cloth : alk. paper)

ISBN 978-0-520-26932-3 (pbk. : alk. paper)

I. East Saint Louis (Ill.)—Social conditions—2Ist century. 2. East Saint Louis (Ill.)-Economic conditions2Ist century. 3. Working class-Illinois-East Saint Louis. 4. African Americans-Illinois-East Saint Louis. I. Title.

HN8O.E27H37 2OII

$305.5^{\prime} 620977389-\mathrm{dc} 22$

2010052399

Manufactured in the United States of America

$\begin{array}{lllllllllll}\text { 20 } & \text { I9 } & \text { I8 } & \text { I7 } & \text { I6 } & \text { I5 } & \text { I4 } & \text { I3 } & \text { I2 } & \text { II } \\ \text { I0 } & 9 & 8 & 7 & 6 & 5 & 4 & 3 & 2 & \text { I } & \end{array}$

In keeping with a commitment to support environmentally responsible and sustainable printing practices, UC Press has printed this book on Rolland Enviroroo, a Io०\% post-consumer fiber paper that is FSC certified, deinked, processed chlorine-free, and manufactured with renewable biogas energy. It is acid-free and EcoLogo certified. 
For my family: Especially to my son, Nile; daughter, Zoe; and spouse, Clarence E. Lang; grandmother Frieda Lewis; mom and dad, Elsie and Fohnnie Hamer; mother-in-law, Delores Lang-Patton; sisters, Frieda, Stephanie, Sonnie, Khadija, and Sheri; brothers, Lawrence, Mark, and Tom; nieces and nephews, Rabba, Regge, Mark, Lily, Olivia, Sam, Ben, Fobnnie Dennison (F.D.), and Macy; and the many families and children in East St. Louis, Illinois 
